\title{
Mechanisms For Activating Zakat Banks in Dealing with The Covid-19 Pandemic
}

Ahmed Ramadan Muhammad Ahmad Haris, Saad Gomaa Gomaa Zaghloul, Marina Abu Bakar, Muhamad Mustakim Abd Halim \& Meryem Abous

To Link this Article: http://dx.doi.org/10.6007/IJARBSS/v11-i4/9651

DOI:10.6007/IJARBSS/v11-i4/9651

Received: 10 February 2021, Revised: 14 March 2021, Accepted: 30 March 2021

Published Online: 14 April 2021

In-Text Citation: (Haris et al., 2021)

To Cite this Article: Haris, A. R. M. A., Zaghloul, S. G. G., Bakar, M. A., Halim, M. M. A., \& Abous, M. (2021). Mechanisms For Activating Zakat Banks in Dealing with The Covid-19 Pandemic. International Journal of Academic Research in Business and Social Sciences, 11(4), 158-164.

Copyright: (c) 2021 The Author(s)

Published by Human Resource Management Academic Research Society (www.hrmars.com)

This article is published under the Creative Commons Attribution (CC BY 4.0) license. Anyone may reproduce, distribute, translate and create derivative works of this article (for both commercial and non-commercial purposes), subject to full attribution to the original publication and authors. The full terms of this license may be seen at: http://creativecommons.org/licences/by/4.0/legalcode

Vol. 11, No. 4, 2021, Pg. 158 - 164

http://hrmars.com/index.php/pages/detail/IJARBSS

JOURNAL HOMEPAGE

Full Terms \& Conditions of access and use can be found at http://hrmars.com/index.php/pages/detail/publication-ethics 


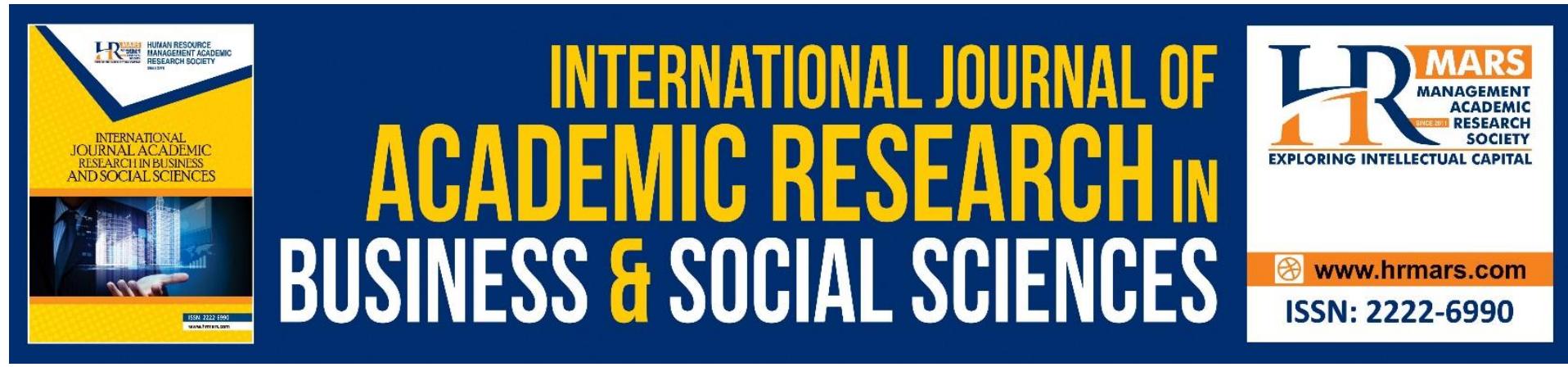

\title{
Mechanisms For Activating Zakat Banks in Dealing with The Covid-19 Pandemic
}

\section{Ahmed Ramadan Muhammad Ahmad Haris ${ }^{1}$, Saad Gomaa} Gomaa Zaghloul2, Marina Abu Bakar ${ }^{3}$, Muhamad Mustakim Abd Halim 4 \& Meryem Abous ${ }^{5}$

${ }^{1}$ Senior Lecturer, Kulliyyah of Sharia \& Law, Sultan Abdul Halim Mu'adzam Shah International Islamic University (UniSHAMS), 09300, Kuala Ketil, Kedah, Malaysia.

${ }^{2}$ Lecturer, Kulliyyah of Sharia \& Law, Sultan Abdul Halim Mu'adzam Shah International Islamic University (UniSHAMS), 09300, Kuala Ketil, Kedah, Malaysia.

${ }^{3}$ Lecturer, Kulliyyah of Sharia \& Law, Sultan Abdul Halim Mu'adzam Shah International Islamic University (UniSHAMS), 09300, Kuala Ketil, Kedah, Malaysia. ${ }^{4}$ Lecturer, Kulliyyah of

Sharia \& Law, Sultan Abdul Halim Mu'adzam Shah International Islamic University (UniSHAMS), 09300, Kuala Ketil, Kedah, Malaysia. ${ }^{5}$ Lecturer, Kulliyyah of Sharia \& Law, Sultan Abdul Halim Mu'adzam Shah International Islamic University (UniSHAMS), 09300, Kuala Ketil, Kedah, Malaysia.

Email: ahw57@yahoo.com, marinaabubakar@unishams.edu.my, saad@unishams.edu.my, mustakim@unishams.edu.my, meriemerie525@gmail.com

\begin{abstract}
The Corona pandemic (COVID-19) is one of the most severe pandemics that has swept the whole world without exception, leaving many negative impacts on human societies. Perhaps the most severe of these effects is the economic deterioration of many countries of the world, including the countries of the Islamic world, which are groaning from the repercussions of the COVID-19 pandemic, which negatively affected the economic income of many members of societies and many members of the Islamic community moved from the site of funding for zakat institutions to the site of the beneficiaries of the banks of zakat. With the emergence of the COVID-19 pandemic and the health and economic consequences of this pandemic on all areas of economic activity worldwide without exception, this problem is raised on the scientific area to find practical solutions to mitigate the economic damage to most members of society. Among these solutions, the zakat institutions in Islamic countries are at the forefront in terms of helping the needy and the affected person. This research paper tries to address the relationship of zakat banks in mitigating the negative effects of COVID-19 pandemic and the mechanisms of dealing with this pandemic through the activation of legal zakat banks. This is through the participation of zakat institutions in contributing to the campaign to provide vaccination for COVID-19 and also activating the mechanisms of zakat banks in order to mitigate the economic damages that have greatly affected the economic side of society. The study aims to analyse the economic damage because of COVID-19 pandemic, the importance of zakat institutions in helping to mitigate the economic damages
\end{abstract}


and activating the mechanisms of legal zakat banks. The researchers use qualitative method of study to conduct this research. The data in this research was collected through library research approach and the analysis was done using content analysis method. The importance of the research appears given that the zakat banks include a large sector of those who need financial assistance in normal circumstances, and as a matter of priority in such a pandemic that affected the whole world without exception. Hence the importance of the research in shedding light on the mechanisms of activating zakat banks in the COVID-19 pandemic.

Keywords: COVID-19, Banks, Zakat Mechanisms

\section{The Negative Effects of Covid-19 Pandemic on the Economy An Overview of COVID-19 Pandemic}

Coronaviruses are a wide variety of viruses that cause illness in animals and humans and infect them with many respiratory diseases, including common colds and severe acute respiratory syndrome known as SARS. However, the Corona viruses triggered a new virus known as COVID-19, which first identified in Wuhan, China, in December 2019. There was no prior knowledge of the spread of this new virus until it appeared in Wuhan, China. It has now transformed into a global pandemic that has afflicted every country in the world. This virus involves a wide range of symptoms, including fever, dry cough, exhaustion, headache, and loss of smell and taste, as well as trouble breathing and nasal congestion. The rapid spread of this virus is due to the fact that the signs of infection do not occur on the infected person if he is infected with the COVID-19 virus, and the person may be infected with the virus but not showing symptoms of the disease until two weeks have passed. One of the factors that contributed to the spread of the pandemic is that it is spread by infectious people touching items and objects on which the virus droplets fall from their mouths or noses when they talk, cough, or sneeze. As a consequence, some countries have decided to decrease the number of individuals in all sectors of the state, closed many clubs and entertainment venues, and many economic sectors in the country to minimize the interpersonal mixing and restrict the spread of the COVID-19 virus. This virus spreads among the elderly who have chronic illnesses including cancer, high blood pressure, heart disease, and diabetes.

\section{The Negative Effects of The Emerging COVID-19 Pandemic on The Global Economy}

With the spread of the new Corona virus (COVID-19 pandemic) at the beginning of the year 2020, there were accompanying precautionary measures taken by many countries of the whole world; between tightening measures or closing the borders. It also limits the movement of individuals into the country. All of this negatively affected the local economy and the scientific economy. Clemens Pressinger explains in his article entitled "The Economic Impact of Coronavirus on Tourism and Remittances" that the economic impacts of the emerging times of the Coronavirus (COVID-19) are increasingly affecting countries that fall into the low-and middle-income brackets, as well as poor countries. The controls that were signed on the international travel sector, as well as the complete or partial closure imposed on companies and industries in Asia, Europe and North America resulted in the collapse of global travel traffic, noting that they are expected to reduce the flow of remittances. Tourism and remittances are important sources of employment and income generation for the poor, respectively (International Food Policy Research Institute, 2020).

No country in the world is spared from these negative effects on the scientific economy. Even the major countries have been exposed to these negative effects on the economy, including the United States of America; which is considered the strongest global economy. So far, many 
Islamic countries have not escaped from these negative effects on the economies of those countries that already suffered from economic weakness before COVID-19. In fact, most Islamic countries are considered developing countries, and sometimes we find a large segment of their population below the poverty line.

The stock and commodity markets in China have undergone a noticeable decline since the announcement of the spread of the Coronavirus (COVID-19) in China, and the impact of this virus extended to both the Asian and American markets, as the spread of the virus restricted travel and trade between countries. All of these have increased spending on the precautionary process to limit its spread. In a related context, OANDA'S chief market analyst, Edward Moya, says that concerns are growing that the travel ban will have a significant impact on the economy, while some are concerned about a drop in Chinese GDP by $1 \%$ or even more during the first quarter of 2020. The loss of China alone has exceeded about $\$ 20$ billion during the past few days, especially since the incubation period for the person infected with the emerging COVID-19 pandemic is much greater than the rest of the other viruses. It is about 10 days, which could lead to an economic recession that puts pressure on public health financing, further weakening the world's ability to prevent or contain the virus outbreak after that (Al-Watan News, 2020).

\section{The Expected Rate of Recovery of The Global Economy}

International organizations, for their part, expect a gradual recovery during the year 2021, nominating certain countries to lead global growth during the new year, especially China. At a time when it is believed that a full recovery from the repercussions of the pandemic may take two to three years, most likely; in order for the global economy to return to the same levels as before the outbreak of the epidemic. This was confirmed by the President of the World Bank, David Malpas, a few days ago, the COVID-19 virus that has killed more than 1.5 million people around the world since the beginning of the year, accompanied by several hopeful developments, including an increase in detection tests about Corona, as well as finding vaccines for the virus, which strengthens expectations for a gradual recovery of the crisis.

It is expected that the rate of contraction in 2020 will reach 4.4 percent, which is less severe than the rate that was expected by the International Monetary Fund last June, according to the "Global Economic Outlook Update", reflecting better than expected GDP results in the second quarter of the year, especially in advanced economies, where activity began to improve more quickly than expected after the general closure was eased in May and June 2020 (Sky News Arabia, 2021).

\section{Mechanisms for Activating Zakat Banks to Mitigate The Effects of Covid-19 Pandemic on The Global Economy}

Knowing the zakat banks, their importance and the mechanisms of spending on them

It is known that one of the tasks of any zakat institution is that it is concerned with two basic parts. The second part is the disbursement of zakat on the items that are legally due for them and which are determined by the verse of Surat At-Tawbah, verse 60:

"Zakah expenditures are only for the poor and for the needy and for those employed to collect [zakah] and for bringing hearts together [for Islam] and for freeing captives [or slaves] and for those in debt and for the cause of Allah and for the [stranded] traveller - an obligation [imposed] by Allah. And Allah is Knowing and Wise". (At-Tawbah; 60) 
With the emergence of the COVID-19 pandemic, zakat institutions can play a major role in helping to mitigate the economic damage caused by this pandemic. This is by activating the mechanisms of the legal zakat dispensing that are stipulated in the aforementioned noble verse, and as stated in the guidance of the Messenger of God to Mu'adh bin Jabal when he sent him to the right, he said to him: "You come to the People of the Book, so call them to testify that there is no god but God and that I am the Messenger of God. If they obey you for that, then teach them that God prescribes five prayers on them every day and night. They obeyed you. Therefore, beware of the crimes of their wealth and fear the supplication of the oppressed, for there is no veil between it and God" (Narrated by Ahmad, Bukhari, Muslim, Abu Dawud, al-Tirmidhi, al-Nasa'i, and Ibn Majah) (Al-Bukhari, 2001; Al-Tirmidhi, n.d).

The bank in terms of language can be defined as an entity that collects, spends and disburses money (Ibn Manzur, n.d) including zakat banks, meaning those who are entitled to it, and it is also used in par with the rate. Allah says: "And the evildoers will see the Fire, then apprehend that they are falling into it, and will find no escape from it" (Al-Kahf; 53). Al-Qurtubi mentioned the rate here referred to any rate as stipulated in Islam (Al-Qurtubi, 2006). Technically, banks refer to bodies in which things are disbursed, including those who spend zakat, that is, those who are entitled to them (Abu Habib, 1988) expressed in charity in the Almighty said: "Zakah expenditures are only for the poor and for the needy and for those employed to collect [zakah] and for bringing hearts together [for Islam] and for freeing captives [or slaves] and for those in debt and for the cause of Allah and for the [stranded] travellers - an obligation [imposed] by Allah. And Allah is Knowing and Wise". (At-Tawbah; 60) (Qala Ji \& Muhammad Rawas, 1988).

From this Quranic text, it becomes clear that the zakat is spent to eight recipients, and accordingly it is not permissible to spend the zakat to others. The verse indicates that there is no right to alms to anyone except for these eight types, and that is unanimously agreed upon. Also, the word "Innama" denotes the restriction and is indicated by faces: First: The word "Innama" is a combination of "that" and "what", the word "Inna" for proof, and the word " $m a$ " is for denial". When they met, they should remain on this concept, so they must prove that the aforementioned is proven, and nothing contradicts it (Al-Razi, 2000). This is a matter unanimously agreed upon (Ibn Qudamah, 1968). In explaining the aid to those seeking help, it was stated: Rather, the disagreement is in understanding them, so we must understand them, and with others it is not necessary" (Al-Sharbini, n.d). That God presupposed on them charity to be taken from their rich so it would return to poor). On top of zakat spending comes the poor and needy as they are the basis and the rest of the items according to them, especially in those emergency conditions that resulted from COVID-19 and the economic recession caused in most areas of life.

Therefore, there must be a specific mechanism by the Zakat Department that enables it to count the poor and needy and circulate them in giving throughout its affiliated department, especially the villages and hamlets far from the central administration of zakat and its subdepartments and their generalization in giving, where there are many poor and needy people who do not reach them the Zakat they deserve due to their distance from cities, or because they are ignorant of what the Zakat Foundation provides them with in terms of services and assistance. One of the researchers mentioned the suffering of such poor and needy people in obtaining subsistence benefits from the Zakat Foundation. It is the duty of the institution to extend a helping hand to such people, and giving and assistance is not limited to the poor who know the way to the institution, and to deal with it only, and this does not mean in any 
way a diminution of the effort that the institution exerts in helping the poor and needy (Zakat and Income Saudi Arabia 2020, Zakat Fund Jordan, 2020).

\section{Mechanisms for Establishing Economic Projects that are Owned by the Poor and Needy}

It is recognized that the purpose of zakat is not merely to satisfy the hunger of the poor and needy, and it is not intended to give the poor one or two dirhams to fill his vacancy for a limited period after which he returns to the question and humiliation. The purpose of zakat is to help the poor and needy to live a decent life, and from this point of view it was narrated from our master Umar, may God be pleased with him, that he said: "If you are given, you will be rich." He also showed him evidence that his policy towards the poor and needy is to enrich himself, so he said: "Let me repeat alms to them, even if one hundred camels go to one of them." It is well known that camels have their value at that time and were considered one of their most valuable money. Establishing projects for the poor and needy and owning them according to what is good does not deviate from what was decided by many jurists when they talked about the amount that is given to the poor. The Shafi'i jurists have argued that the poor is given what suffices him for his long life, and what brings him out of poverty to the rich (Al-Nawawi, 2001; Al-Bujairimi, 1996), and they cited the hadith of Qubaysah that the Prophet PBUH said: "The issue is solved only for one of three men carrying a stretcher, so the issue is resolved for him until he hits it and then he catches, and a man who was hit by a pandemic and resolved the issue for him until he hits a sustenance - or he said a supply of sustenance , and a man hit him in need until he says three of the pilgrims of his people: It has afflicted soand-so, so desperate, and the matter has been resolved for him until he suffers a sustenance of sustenance, or he said a repayment of sustenance, so what else is the matter". The Prophet PBUH stated that the person who is entitled to zakat is given until he is rich and is able to take care of himself and his dependents, and this does not happen except by giving him the full sufficiency of his sufficiency, and in order to ensure the optimum utilization of this amount that is given to the poor, he prefers to establish a project for him commensurate with his abilities and the craft he mastered that the ruler or whoever does it In his own hands, the management of zakat is like an institution of zakat. It says in total: "If his habit of professionalism gives what he buys the machines of his craft, the value of that is less or more, and his value is such that he gets from his profit what is almost sufficient for him.

This opinion was supported by the contemporary zakat jurist, Sheikh Yusuf al-Qaradhawi, who said: "The Muslim state can establish factories, real estate, commercial establishments from zakat funds and own them all or part of the poor in order to generate income for them that fully suffices them, and does not give them the right to sell it and the transfer of its ownership to remain semi-financed by them" (Al-Qaradhawi, 2009).

\section{Conclusion}

In conclusion, it is very important to activate the mechanisms of zakat banks. This can be done by directing zakat institutions operating in Islamic countries to contribute alleviating the economic damage that resulted from the COVID-19 pandemic. For example, by contributing to alleviate the suffering of the poor and the needy from zakat recipients, as well as the rest of the legitimate banks stipulated in the verse of Surah At-Tawbah. It is recommended that zakat institutions contribute to bear the costs of treating the poor. Thus, it is permissible according to the opinion of the jurists who went to expand the giving of the poor. Whoever says that the poor is given a year's sufficiency, it is permissible to bear the expenses of his treatment for a year, given that the treatment is complete sufficiency, and whoever says that 
he is given the sufficiency of the predominant life, then the institution may bear the expenses of his treatment on an ongoing basis.

\section{References}

Al-Qur'an al-Karim.

Abu Habib, S. (1988). Al-Qamus al-Fiqhi Lughatan Wa Istilahan. Second Edition. Syria: Dar al-Fikr.

Al-Bujairimi, S. bin O. bin M. (1996). Hashiah al-Bujairimi 'ala al- Khatib. Beirut: Dar alKutub al-'llmiyyah.

Al-Bukhari, M. bin I. (2001) Sahih al-Bukhari. Beirut: Maktabah al- 'Asriyyah,

Al-Nawawi, I. Abu Z. Y. bin S. (2001). Syarh Sahih al-Muslim. Fourth Edition. Cairo: Dar al-Hadith.

Gee, Q., \& Rawas, M. (1988). Mu'jam Lughah al-Fuqaha. Second Edition. Jordan: Dar alNafais.

Yusuf, I-Q. (2009). Figh al-Zakah. First Edition. Egypt: Dar al-Risalah al- 'Aalamiyyah.

Al-Qurtubi, A. M. (2006). Al-Jami' Li Ahkam Al-Qur'an. Beirut, Lubnan: Muassasah alRisalah.

Al-Razi, F. M. bin O. (2000). Mafatih al-Ghaib. First Edition. Beirut, Lebanon: Dar al-Kutub al'Ilmiyyah.

Sky News Arabia. (2021). Corona hostage: What awaits the world economy in 2021? https://www.skynewsarabia.com/business/1403375-. [Retrieved on 2 February 2021].

Al-Tirmidhi, M. bin I. (n.d). Al-Jami' al-Sahih. Lebabon: Ihya' al-Turath al- 'Arabi.

Ibn Hanbal, Abu A. A. Ibn M. Ibn H. (1998). Al-Musnad. Beirut: 'Aalimu al-kutub.

Ibn Manzur, M. bin M. bin M. (n.d). Lisan al-Arab. Beirut: Dar Sadir.

Ibn Qudamah, Abu Muhammad Abdullah bin Ahmed bin Muhammad bin Qudamah (1968). Al-Mughni. Egypt: Maktabah al-Qahirah.

International Food Policy Research Institute. (2020). IFPRI Insights. https://www.ifpri.org/newsletter/ifpri-insights-april-2020. [Retrieved on 28 December 2020].

Al-Islami, M. A. (2020). Economic Impact Caused by The New Corona Virus

Epidemic (COVID-19) On the Tourism Sector and Financial Transfers: Insight from https://democraticac.de/?p=67683. [Retrieved on 28 December 2020]

Egypt.

Al-Watan News. (2020). https://alwatannews.net/article. [Retrieved on 28 December 2020].

Zakat and Income Saudi Arabia. (2020). The official website of Zakat and Income Saudi Arabia. www.dzit.gov.sa.

Zakat Fund, Jordan. (2020). www.zakatfund.org. 